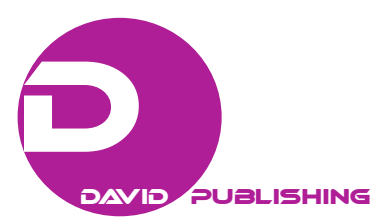

\title{
Dominant Factors Influence the Behavior to Produce Innovative Products
}

\author{
Iffah Budiningsih \\ As-Syafi'iyah Islamic University, Jakarta, Indonesia \\ Tjiptogoro Dinarjo Soehari, Jefri Leonard \\ Mercubuana University, Jakarta, Indonesia
}

\begin{abstract}
The rapid advancement of science and technology in the era of business competition, as it is today, has an impact on a very dynamic business environment, and requires organizations/companies to have human resources (employees) that are innovative and responsive to the advancement of science and technology. Schools and universities must contribute to preparing generations who have the ability to innovate for every employee who works in an agency/company. The purpose of this study is to study the dominant factors that influence behavior to produce innovative products. The quantitative approach was used in this study with survey methods. The sample of this study is 100 employees who are one of the companies in the field of technology services in Jakarta, including: markets, volunteer websites, portals, and selected by purposive sampling. Data were obtained by distributing questionnaires and analyzed using regression. Regression analysis is used to determine the model of the relationship between behavior to produce innovative products $(Y)$ with entrepreneurial leadership $(X 1)$ and creativity $(X 2)$. The results of the study are: (1) Entrepreneurial leadership and creativity collectively have a positive influence to improve behavior towards innovative behavior; (2) leadership and entrepreneurial creativity collectively contribute to improving behavior to produce innovative products at $77 \%$ and $23 \%$ of other factors; (3) entrepreneurial leadership and creativity "cannot be ignored" as an instrument to improve behavior to produce innovative products; (4) improving behavior to produce innovative products can be predicted by increasing entrepreneurial leadership and creativity by using a simple regression model $Y=0.61+0.47 X 1+0.41 X 2$.
\end{abstract}

Keywords: entrepreneurial leadership, creativity, behavior to produce innovative products

\section{Introduction}

This competitive business era has become a challenge for every businessmen or company. This competitive business condition demands the businessmen to carry out various efforts and strategies for their survival in this competitive environment. Among many business capitals, human resource or human capital is one of the most crucial capitals. It is an active capital that serves to optimize other capitals, such as financial, information, and resource capitals. The rapid advancement of science and technology in this competitive era

Iffah Budiningsih, doctor, lecturer, Faculty of Education, As-Syafi'iyah Islamic University, Jakarta, Indonesia.

Tjiptogoro Dinarjo Soehari, doctor, lecturer, post graduade, Mercubuana University, Jakarta, Indonesia.

Jefri Leonard, magister management, Alumni of Mercubuana University, Jakarta, Indonesia.

Correspondence concerning this article should be addressed to Iffah Budiningsih, Vice Rector in Academic Affairs, As-Syafi'iyah Islamic University, Jl. Raya Jatiwaringin No. 12 Pondok Gede, Jakarta 17411, Indonesia. 
has created a more dynamic business environment, which demands organizations/companies have innovative and responsive employees that can adeptly respond and adapt to this science and technology advancement. Immediate and appropriate response toward this rapid change needs innovation from each employee to create and provide innovative products and services. Thus, their products will be able to compete in the market. This study is carried out in a start-up company which business is in providing IT services, such as market place, volunteer website, and portal.

This study aims at finding out the extent of entrepreneurial leadership and creativity as dominant factors in increasing the behavior to produce innovative products. The educational process from elementary to higher education institution plays an important role in shaping and preparing human resources that are able to appropriately and quickly respond to the rapid change of science and technology, especially in the way of products and services are produced. This study is expected to become reference for the educators in all level of education to develop prominent character within the curriculum which can create learning outcomes with the characteristics of ability to produce innovative products needed by the market; as well as become a reference for businessmen/practitioners to develop innovative characters within their employees that are able to create products and services.

Entrepreneurial leadership is a characteristic of a leader which is strongly related to one's concept or ideas in supporting the business to achieve its maximum outcome. This idea and concept encompass the vision and mission, decision-making, implemented strategies, etc. Leader's characteristic in business brings about inspiration and motivation for employees and partners to be able to see and capture opportunities, aside from its managerial directions as his main competencies as a role model in entrepreneurship culture, and therefore, each business unit needs entrepreneurial leader. This often becomes a competitive advantage in a strongly competitive business environment and the rapid advancement of IT. Currently, many companies collapsed due to unavailability of entrepreneurial leadership character.

Creativity is a process of thinking that creates the ability to reflect the originality, ingenuity, flexibility to elaborate new ideas, and a new perspective of looking at problems. Creative people use their knowledge to create a leap that enables them to see things and solve problems from a new perspective. Ability to create new innovative products in the competitive business era of today is in need of creative people. The hypothesis in this study is that entrepreneurial leadership and creativity are dominant factors that influence the behavior to innovative products.

\section{Literature Review}

\section{The Behavior to Produce Innovative Products}

Innovation is how an entrepreneur manages available resources to create a beneficial outcome. Innovation is needed in a currently competitive business environment of today, not only in big companies but also on many levels of governmental organizations and small to medium scale organizations. When an organization does something differently, looks for a new area, and is willing to take the risk, then it can be said that the organization has been doing an innovation. This is in line with Robbins and Coutler (2012, p. 16) which stated that innovation is one's activity to do something in different ways than others explore new potentials and are willing to take the risk. Innovation is not only related to IT but also on doing business different from usual practice. Further, Carmeli and Spreitzer (2009, pp. 169-191) described innovative behavior of a person in his job is the basis to achieve high performance in organization; this is due to the innovative behavior that plays an 
important role in increasing the competitive advantage of the organization and encourages people to achieve more and differently regardless of the limited resources; thus, innovative behavior utilizes limitations through optimization of ideas/new ideas, hence, a more valuable product/service is created. This shows that one's innovative behavior is a process to recognize problems to create or adopt new ideas/solutions to accomplish a task. Hence, it gains support from the environment or creates a new prototype or model that can be applied to benefit the organization or units within the organization.

West and Farr (1989), as cited by Kleysen and Street (2001, pp. 284-296), defined the innovative behavior of employee as one's action to provide or introduce new invention (application of method/new way of doing things) which can benefit the organization/companies. The newly invented things can be in forms of: (a) ideas for the development of new products; (b) technological development; (c) revitalization of administrative procedure; (d) increasing work relationship; and (e) application of new ideas or technology to significantly increase efficiency and effectiveness of the employees.

Further, Carmeli, and Spreitzer (2009), as cited by Barrand, Sanseau, and Ferrante (2012, p. 146), described that in general innovative behavior involves three stages of:

- First: A person recognizes a problem then finds a solution and a new idea or adopt new ideas or solutions;

- Second: A person finds a way to promote the ideas or solutions that he found to develop legitimation and support from within and outside the organization;

- Third: A person implements ideas or solutions in his job by producing the prototype or innovation model that can be applied within the organization.

Rogers (1995, p. 190) stated that there are five stages that show a person is innovative:

- Knowledge stage: collect and understand messages, knowledge, or skills for effective innovation adaptation;

- Persuasion stage: like the innovation, discussing the new ideas, acceptance of the innovation, positive thinking toward the innovation; and seeking support toward the innovative behavior within the environment.

- Decision stage: tries to find additional information on the innovation and tries out the innovation.

- Implementation stage: find additional information on the innovation, start using the innovation, and continuous usage of innovation;

- Confirmation stage: acknowledge the usage of innovation, integrate of innovation within the business process, and promote innovation to others.

Kleysen and Street (2001, pp. 284-296) supported Roger's statement by stating that there are five dimensions to assess level of one's innovation:

- Exploration of opportunity: provide attention, seek, acknowledge, and collect information on the opportunity.

- Focus on positive change: how is the idea/solution, categorizing chances (easy or difficult), and application of a combination of ideas and information;

- Try out: try out the ideas/solutions;

- Seek support: mobilize resource, persuade, influence, encourage, negotiate, and take risk,

- Implementation: implement, modify, and habituate.

Fauziah, Iffah, Adnan, and Masduki (2017, p. 34) stated that one's innovative behavior is an individual effort directed to create, introduce, or apply new invention like beneficial ideas or solutions for business activity which indicate the existence of developing ideas, seeking opportunity, introducing the ideas, seeking solution, and implementing the ideas. 
Based on this description, it can be concluded that the behavior to produce innovative product is one's efforts which directed toward finding, producing, introducing, and applying the newly invented "products" either ideas, solutions, or technologies that are beneficial for human activity to indicate the existence of seeking/looking for opportunity, developing ideas, looking for support to implement, and implementing the new ideas.

\section{Entrepreneurial Leadership}

The concept of entrepreneurial leadership is the combination of two words leadership and entrepreneurship as this concept is derived from the exploration of leadership and entrepreneurship behavior concept. Hisrich-Peters in Alma (2006, p. 21) described entrepreneurship as a process to create something that is different from others through: (a) utilization of time; (b) provision of capital or financial, personal, and social risk; (c) acceptance of return; (d) the existence of satisfaction; and (e) personal freedom. In this case, entrepreneurship is related to the existence of findings or invention of ideas that are different from the currently available. Marbun in Alma (2006, p. 45) stated that an entrepreneur has to have the following characteristics: self-confidence, result oriented, risk taker, leadership, originality, and future-oriented. In reference to several definitions of entrepreneurship and characteristics of entrepreneurs, entrepreneurship is a process of finding or creating new ideas/services which are different from others or the currently available which indicates the willingness to provide time, willingness to provide capital or financial/personal/social risk and accept return, and existence of personal satisfaction and freedom.

In general, leadership is one's ability to mobilize, synchronize, mobilize a group, and describe ideas thus other understands acknowledge and follow the ideas. Robbins and Judge (2007, p. 354) described the characteristics of leaders, such as smart, easy to interact with others, confident, honest, trusted, and responsible, able to state ideas, passionate, and have good morale. Gary A. Yukl (1998, p. 2) exposed that leadership is a collective mobilization which impacted on collective willingness to make efforts to achieve common goals and targets. Further, Ireland and Hiit in Karmarkar, Chabra, and Deshpande (2014, p. 161) described that the indicators for entrepreneurial leadership are: the ability to motivate, ability to influence other, setting direction, communicating aptly, developing changes, managing strategic resources, encouraging other to have competitiveness, and aptitude in seeking for opportunities.

Based on the above description, it can be said that entrepreneurial leadership is one's ability to do collective mobilization which impacted on the collective willingness to do something together to always do innovation or creation of new ideas through future-oriented motivation, seeking opportunity, always develop changes, outcome-oriented mobilization, always willing to take risk, and always passionate and persistent.

\section{Creativity}

In daily lives, creativity is essential as creativity is a crucial ability in a man's life; creativity is an ability to create new ideas/ways/products to overcome various problems in life. According to Linda Naiman (2014), creativity is an act to change new ideas and imaginations into real products/services. Further, she described that creativity is characterized by the ability to see something from a new perspective which is useful to find currently unavailable concepts, to create correlations between phenomena that are previously unrelated, or to create various solutions for complex problems. Creativity involves two processes: thinking process based on knowledge and production process in forms of products/services. If we have ideas that do not follow by producing those ideas, then it is called "imaginative but not creative". Therefore, creativity is one's conscious 
hard-work to utilize knowledge to create a leap that enables the solving of problems. According to Semiawan (1997, p. 50), creativity is related to basic human function, to always think, sense, feel, and intuitive. Whereas, according to Munandar (2011), creativity is an ability that reflects flexibility and originality in thinking as well as the ability to elaborate ideas (develop, enrich, and detailing). This definition highlights the change process due to innovation and variation.

Rogers in Munandar (2011, p. 114) proposed several factors that influence creativity: internal factors (openness attitude, internal locus of evaluation, and willingness to experiment) and environmental factor. Rogers in Munandar (2011, p. 115) further explained that environmental factor that can be utilized to develop one's creativity is characterized by the environment that provides psychological security (accept people the way they are, without any external evaluation, and empathy toward each other) and psychological freedom (freedom of expression). According to Guilford in Semiawan (1997, p. 49), one's creativity test item can be seen on how he responds toward the stimulus: their fluidity, flexibility, originality, and elaboration. Siyana Sokolova (2015) described that employees creativity can increase problem-solving process through creative and innovative ideas from every aspect, either partner, customers, targets, or employees themselves; therefore, openness to sharing ideas with partners, customers, employees, and targets need to be developed and encouraged by the organization.

From various definitions above on creativity, it can be concluded that creativity is the ability to transform new imaginative ideas into real products/services, which indicated by openness, freedom of expression, fluidity to explore ideas, high flexibility, favoring originality, and high elaborative ability.

\section{Research Method}

The objective of this research is to test the influence of entrepreneurial leadership $(X 1)$ and creativity $(X 2)$ toward the behavior to produce innovative product $(Y)$. The research method used in this study is correlational survey between independent variables $(X 1$ and $X 2)$ and the dependent variable $(Y)$. This research used correlation and regression analysis to determine the simultaneous correlation \& model between variable $X 1$ and $X 2$ toward $Y$ variable. The population target in this study is the employees in start-up companies that work in providing IT services, such as the marketplace, volunteer website, and portal with the total of 125 employees and 100 employees are taken as the sample through simple random sampling technique. The data collected using Likert scale questionnaire with the following category: 5 = "Strongly agree", 4 = "Agree", 3 = "Neutral", 2 = "Disagree", 1 = "Strongly disagree". The data from this research are analyzed using descriptive analysis (centralistic tendency) and inferential analysis (correlational analysis and multiple linear regressions) through the SPSS program for Windows.

\section{Research Variables and Indicators}

Variables in this research consist of the dependent variable $(Y)$, the innovative behavior of producers; whereas the independent variables are entrepreneurial leadership (X1) and creativity $(X 2)$ which formulated as: $Y=\mathrm{a}+\mathrm{b} X 1+\mathrm{c} X 2+€$. Each variable has indicators that are described in Table 1.

\section{Validity Test \& Reliability Test of the Research Instrument}

Prior to the administration of the instrument in the research, it is tried out to 30 respondents to test its validity by using the Pearson Product Moment formula; whereas the reliability of the instrument is tested using the Alpa Cronbach. The result of the validity test of the instrument for the behavior to produce innovative products $(Y)$, entrepreneurial leadership $(X 1)$, and creativity $(X 2)$ is presented in Table 2: 
Table1

Instrument Summary of $Y, X 1$, and X2 Variables

\begin{tabular}{|c|c|c|}
\hline Variables & Indicator & Likert scale \\
\hline \multirow{4}{*}{$\begin{array}{l}\text { The behavior to produce innovative products } \\
(Y)\end{array}$} & a. Existence of seeking/looking for opportunity & \multirow{4}{*}{ Ordinal $1 \mathrm{sd} 5$} \\
\hline & b. Developing ideas & \\
\hline & c. Looking for support to implement & \\
\hline & d. Implementing the new ideas. & \\
\hline \multirow{6}{*}{ Entrepreneurial leadership (X1) } & a. Future-oriented motivation & \multirow{6}{*}{ Ordinal 1 sd 5} \\
\hline & b. Always develop changes & \\
\hline & c. Outcome-oriented mobilization & \\
\hline & d. Always willing to take risk & \\
\hline & e. Always passionate & \\
\hline & f. Persistent & \\
\hline \multirow{5}{*}{ Creativity $(X 2)$} & a. Openness \& freedom of expression & \multirow{5}{*}{ Ordinal 1 sd 5} \\
\hline & b. Fluidity to explore ideas & \\
\hline & c. High flexibility & \\
\hline & d. Favoring originality & \\
\hline & e. High elaborative ability & \\
\hline
\end{tabular}

Table 2

Validity and Reliability Test Result for Variables $Y, X 1$, and X2

\begin{tabular}{|c|c|c|c|c|c|c|}
\hline No. & Variables & $\begin{array}{l}\text { Valid question } \\
\text { item }\end{array}$ & $\begin{array}{l}R \text { count } \\
\text { (Pearson) }\end{array}$ & $R$ table $(\alpha: 0.05)$ & $\begin{array}{l}\text { Reliability } \\
\text { coefficient }\end{array}$ & Note \\
\hline 1 & $\begin{array}{l}\text { Behavior to produce innovative } \\
\text { product }(Y)\end{array}$ & 10 & $0.36-0.83$ & 0.20 & 0.93 & Valid \& reliable \\
\hline 2 & Entrepreneurial leadership $(X 1)$ & 10 & $0.30-0.78$ & 0.20 & 0.86 & Valid \& reliable \\
\hline 3 & Creativity $(X 2)$ & 10 & $0.59-0.85$ & 0.20 & 0.96 & Valid \& reliable \\
\hline
\end{tabular}

\section{Results and Discussion}

\section{Descriptive Analysis}

The descriptive analysis in this study consists of centralistic tendency to see the average and the standard error of mean for the bevavior to produce innovative products $(Y)$, entrepreneurial leadership (X1), and creativity (X2). The score of the data using a Likert scale, 5 = "Strongly agree", 4 = "Agree", $3=$ "Neutral", $2=$ "Disagree", 1 = "Strongly disagree". The average (mean) opinion of 100 respondents toward the indicator of behavior to produce innovative product $(Y)$, shows the score of 3.60 (rounded up to $4=$ "Agree") with the standard error of mean $=0.24$, which means that the average respondents "agree" with the indicator of behavior to produce innovative product of employees as producers in the company where are currently working. The mean score for entrepreneurial leadership (X1) is 3.612 (rounded up to $4=$ "Agree") with the standard error of mean $=1.93$ which means that the average respondents the indicators of entrepreneurial leadership that should exist in company's leader. In addition, the mean for creativity variable $(X 2)$ shows a score of 3.687 (rounded up to 4 = "Agree") with the standard error of mean 0.2 which means that the average respondents "agree" with the creativity indicators that should be found in each employee of a company.

\section{Correlational Analysis and Multiple Regression Analysis}

Normality and homogeneity analysis is carried out before the correlation and multiple regression analysis is carried out. In this study, both requirements are fulfilled, where variables $Y, X 1$, and $X 2$ have a normal 
distribution and the variance is homogenous. The correlation analysis reveals that the entrepreneurial leadership $(X 1)$ and creativity $(X 2)$ simultaneously correlate with the behavior to produce innovative products $(Y)$ with the multiple correlational coefficients of $R=0.879$ (see Table 3). This shows that simultaneously the entrepreneurial leadership $(X 1)$ and creativity $(X 2)$ have "strong and positive" correlation with the behavior to produce innovative products $(Y)$. Further, the determinant coefficient $(R$ square $)=0.773$ shows that the contribution of these two independent variables: entrepreneurial leadership (X1) and creativity $(X 2)$ toward the establishment of the behavior to produce innovative products $(Y)$ is $77.30 \%$ and the rest $22.70 \%$ is determined by other factors. The result of multiple correlation coefficient analysis and determinant analysis produced through the SPSS program is presented in Table 3.

Table 3

Multiple Correlations Coefficient X1, X2, and $Y$

\begin{tabular}{llllllllll}
\hline \multirow{2}{*}{ Model $R$} & \multirow{2}{*}{$R$ Square } & $\begin{array}{l}\text { Adjusted } R \\
\text { Square }\end{array}$ & $\begin{array}{l}\text { Std. the error of the } \\
\text { Estimate }\end{array}$ & $\begin{array}{l}\text { S Square } \\
\text { Change }\end{array}$ & F Change & df1 & df2 & $\begin{array}{l}\text { Sig. F } \\
\text { Change }\end{array}$ \\
\hline 1 & $0.879 \mathrm{a}$ & 0.773 & 0.768 & 0.34695 & 0.773 & 165.110 & 2 & 97 & 0.000 \\
\hline
\end{tabular}

Note. a. Predictors: (Constant), X2, X1.

The result of variance analysis (ANOVA) of correlation between entrepreneurial leadership (X1) and creativity $(X 2)$ simultaneously toward the behavior to produce innovative products $(Y)$ is presented in the following Tables 4 and 5.

Table 4

ANOVA

\begin{tabular}{llllll}
\hline Model & Sum of squares & df & Mean square & $F$ & Sig. \\
\hline Regression & 39.750 & 2 & 19.875 & 165.110 & $0.000 \mathrm{a}$ \\
Residual & 11.676 & 97 & 0.120 & & \\
Total & 51.426 & 99 & & & \\
\hline
\end{tabular}

Notes. a. Predictors: (Constant), X2, X1; b. Dependent variable: Y.

Table 5

Coefficients

\begin{tabular}{llllll}
\hline \multirow{2}{*}{ Model } & \multicolumn{2}{c}{ Unstandardized coefficients } & Standardized coefficients & & Sig. \\
\cline { 2 - 6 } & $\mathrm{B}$ & Std. error & Beta & 3.539 & 0.001 \\
\hline (Constant) & 0.613 & 0.173 & & 5.798 & 0.000 \\
$X 1$ & 0.469 & 0.081 & 0.480 & 5.349 & 0.000 \\
\hline 2 & 0.419 & 0.078 & 0.443 & 5 & \\
\hline
\end{tabular}

Note. a. Dependent variable: $Y$.

Based on the ANOVA result in Tables 4 and 5, the model of multiple linear regressions can be for the correlation between entrepreneurial leadership $(X 1)$ and creativity $(X 2)$ toward the behavior to produce innovative products $(Y)$ can be formulated as $Y=0.61+0.47 X 1+0.42 X 2$

The significance test toward the regression constant, $a=0.61$ (see Table 5) shows "significant" result, as the value of sig. $<0.05(0.001<0.05)$; this indicates that the constant yields significant influence in the achievement of the behavior to produce innovative products. The result of significance test for regression 
coefficient of $X 1$ is $b=0.47$ (see Table 5) also showing "significant" result, as the value of sig. $<0.05(0.001<$ 0.05 ); and the significance test for regression coefficient for $X 2$, is $\mathrm{c}=0.42$ (see Table 5) which also shows a "significant" result, as the value of sig. $<0.05(0.001<0.05)$. These indicate that the entrepreneurial leadership (X1) and creativity (X2) influence the extent of achievement of the behavior to produce innovative products $(Y)$. The result of significance test toward the multiple linear regression model $Y=0.61+0.47 X 1+$ $0.42 X 2$ shows a "significant" result, as the value of sig. $0.00<0.05$ (see Table 4). This indicates that the model $Y=0.61+0.47 X 1+0.42 X 2$ "is strongly significant and cannot be ignored" to predict the "behavior to produce innovative products" by using the entrepreneurial leadership (X1) and creativity (X2) if both of these data are known. The multiple linear regression model $Y=0.61+0.47 X 1+0.42 X 2$, means that each increase of 10 score unit in entrepreneurial leadership $(X 1)$ and creativity $(X 2)$ will increase/decrease the achievement of the behavior to produce innovative products of the employees as producers, in average by $=0.61+0.47(10)+0.42(10)=9.51$ units in the constant score of 0.61 . If the entrepreneurial leadership value $=0(X 1=0)$, creativity $=0(X 2=0)$, then the behavior to produce innovative products of the employees as producers is only 0.61 units. Thus, without the entrepreneurial leadership (X1) and creativity (X2), the behavior to produce innovative product of the employees as producers will be low. Therefore, entrepreneurial leadership and creativity on employees are necessary for all companies that produce either products or services.

\section{Conclusion}

This study shows that there is a "strong" and "positive" correlation between entrepreneurial leadership (X1) and creativity $(X 2)$ simultaneously toward the behavior to produce innovative product $(Y)$ which indicated by the degree of multiple linear regression coefficient by $R=0.879$. The "significant" correlation is shown by the multiple linear regression model of $Y=0.61+0.47 X 1+0.42 X 2$, this means that: (a) entrepreneurial leadership, creativity simultaneously influence the achievement of behavior to produce innovative products; (b) entrepreneurial leadership and creativity simultaneously contribute toward the achievement of behavior to produce innovative products by $77.3 \%$ and $22.7 \%$ is determined by other factors. The implication of this is that entrepreneurial leadership and creativity are significant or dominant factors to predict the level of behavior to produce innovative products of employees as producers in a company. As Carmeli and Spreitzer (2006, pp. 75-90) as the reference in this study, behavior to produce innovative products of employees as producers in a company is the basis to achieve the optimum performance in their business activity. This is because the behavior to produce innovative products has a significant role in increasing the competitive advantage of the product and encourages people to perform above and differently amidst the limited resources; therefore, the behavior to produce innovative products will make employees optimize ideas to create better new product/service with more added values.

The results of this study provide further implication that human resources (employees) that are innovative and responsive to advances in science and technology should be prepared early on through the institution/school (primary school, middle school, or high school) and college. The institution has a very strategic role and cannot be ignored in form and set up the behavior of young generation of innovative \& responsive to advances in science and technology, through the development of the character entrepreneurial leadership and creativity both in the curriculum (hidden curriculum) or non-curriculum (extra-curricular). 


\section{References}

Alma, B. (2006). Kewirausahaan (Rev. Ed.). Bandung: Alfabeta.

Barrand, J., Sanseau, P. Y., \& Ferrante, G. (2012). The leader-member relationship at the core of innovation development: Member perceptions, positions and expectations. In D. G. Assimakopoulos, E. G. Carayannis, and R. Dossani (Eds.), Knowledge perspectives of new product development: A comparative approach. New York: Springer.

Carmeli, A., \& Spreitzer, G. M. (2009). Trust, connectivity, and thriving: Implication for innovative behavior at work. Journal of Creative Behavior, 43(3).

Curtis, S., \& Wright. D. (2001). Retaining employes: The fast track to commitment. Management Reserach News, 24(8-9).

Fauziah, S., Iffah, B., Adnan, D., \& Masduki, A. (2017). Dominan factors affecting the behavior of innovatove employees. Polish Journal of Manageen Studies (PJMS), 16(1).

Illes, B. C., Dunay, A., \& Jelonek, D. (2015). The enterpreneurship in Poland and in Hungary future enterpreneurs education perspectives. Polish Journal Management Sytudies (PJMS), 16(1), 32-40.

Karmarkar, Y., Chabra, M., \& Deshpande, A. (2014). Entrepreneurial leadership style(s): Taxonomi review. Annual Research Journal of Symbiosis for Management Studies, 2(1), 161.

Kleysen, R. F., \& Street, C. T. (2001). Toward a multi-dimensional measure of individual innovative behavior. Journal of Intellectual Capital, 2(3).

Munandar, U. (2011). Development of talented children creativity. Jakarta: Rineka Cipta.

Naiman, L. (2014). Creativity at work. Retrieved 29.09.18 from https://www.creativityatwork.com/2014/02/17/what-is-creativity

Othman, N., Muhammad, R., Aishah, R. S., \& Rahman, R. A. (2007). Enterpreneurial competency and tendencies among pre-universirty student. Intenational Journal of Economic Reserach (IJER), 14(15), 55-56, 63-64.

Robbins, S, P., \& Coulter, M. (2012). Management. New Jersey: Pearson Education Inc.

Robbins, S. P., \& Judge, T. A. (1998). Organization behavior (12th ed.). New Jersey: Pearson Education.

Roggers, E. M. (1995). Diffusion of innovations (4th ed.). New York: The Free Press.

Semiawan, C. (1997). Perspektif pendidikan anak berbakat. Jakarta: PT. Gramedia Widiasarana (Grasindo).

Shermon, G. (2004). Competrency based HRM: A strategic resource for competency mapping assessment and development centres. New delhi :Tata McGraw Hill Education Private Limited.

Sokolova, S. (2015). The importance of creativity and innovation in business. Retrieved 29.09 .18 from https://www.linkedin.com/pulse/importance-creativity-innovation-business-siyana-sokolova

Yukl, G. A. (1998). Kepemimpinan dalam organisasi. Jakarta: PT Prenhallindo. 